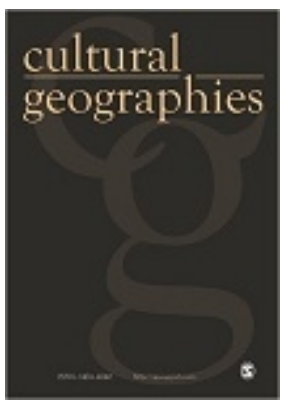

\title{
Nuclear Landscape: Tourism, radiation, embodiment and exposure in the Chernobyl Zone
}

\begin{tabular}{|c|c|}
\hline Journal: & cultural geographies \\
\hline Manuscript ID & CGJ-17-0054.R2 \\
\hline Manuscript Type: & Article \\
\hline Keywords: & $\begin{array}{l}\text { Chernobyl, landscape, tourism, nuclear, radiation, post-phenomenology, } \\
\text { embodiment, Irigaray, Merleau-Ponty, non-representational }\end{array}$ \\
\hline Abstract: & $\begin{array}{l}\text { This paper recounts a day-trip to the Chernobyl Exclusion Zone and the } \\
\text { ruined town of Pripyat through a series of ethnographic vignettes from } \\
\text { the point of view of a tour guide. I argue for the need to research } \\
\text { worldly forces, such as radiation, without reducing them to matters of } \\
\text { language and thought. In order to take on this challenge, the paper } \\
\text { offers an approach that begins with questions of embodiment, } \\
\text { materiality and agency. I introduce the work of Merleau-Ponty as a key } \\
\text { theorist behind landscape geographies. In particular, the rejection of } \\
\text { dualism and distance is shown to be a vital starting point when } \\
\text { understanding tourism and guiding in the radioactive landscape of the } \\
\text { Zone. Through the crackling and chirruping of the Geiger counter, the } \\
\text { halting, careful movements visitors and my own uncertainties I illustrate } \\
\text { how radiation is first encountered as a bodily exposure, which is only } \\
\text { ever apprehended after-the-fact and experienced as vulnerability. I } \\
\text { argue that a more passive, vulnerable sense of embodiment is needed } \\
\text { than phenomenology provides, for which I bring the work of Irigaray into } \\
\text { conversation with recent post-phenomenological work in geography. In } \\
\text { responding to these challenges the radioactive landscape of the } \\
\text { Chernobyl Zone and Pripyat, the paper offers 'exposure' as a model of } \\
\text { subjectification, applicable beyond radioactive landscapes, which is } \\
\text { based upon passivity, vulnerability and a foundational relation-with } \\
\text { worldly others which exceed our perceptual, representational and bodily } \\
\text { capacities. }\end{array}$ \\
\hline
\end{tabular}

\section{SCHOLARONE Manuscripts}




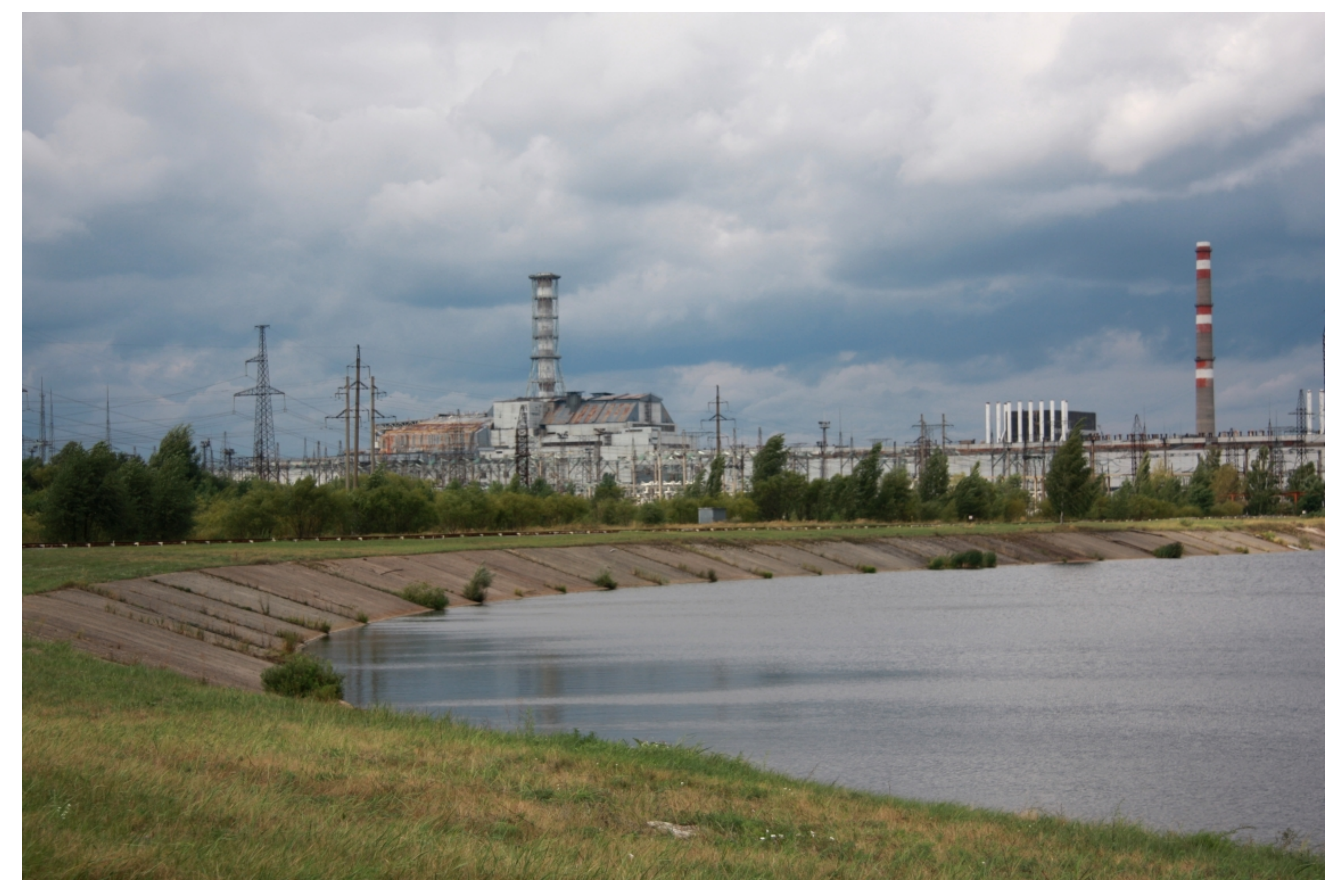

The Chernobyl Nuclear Power Plant. 


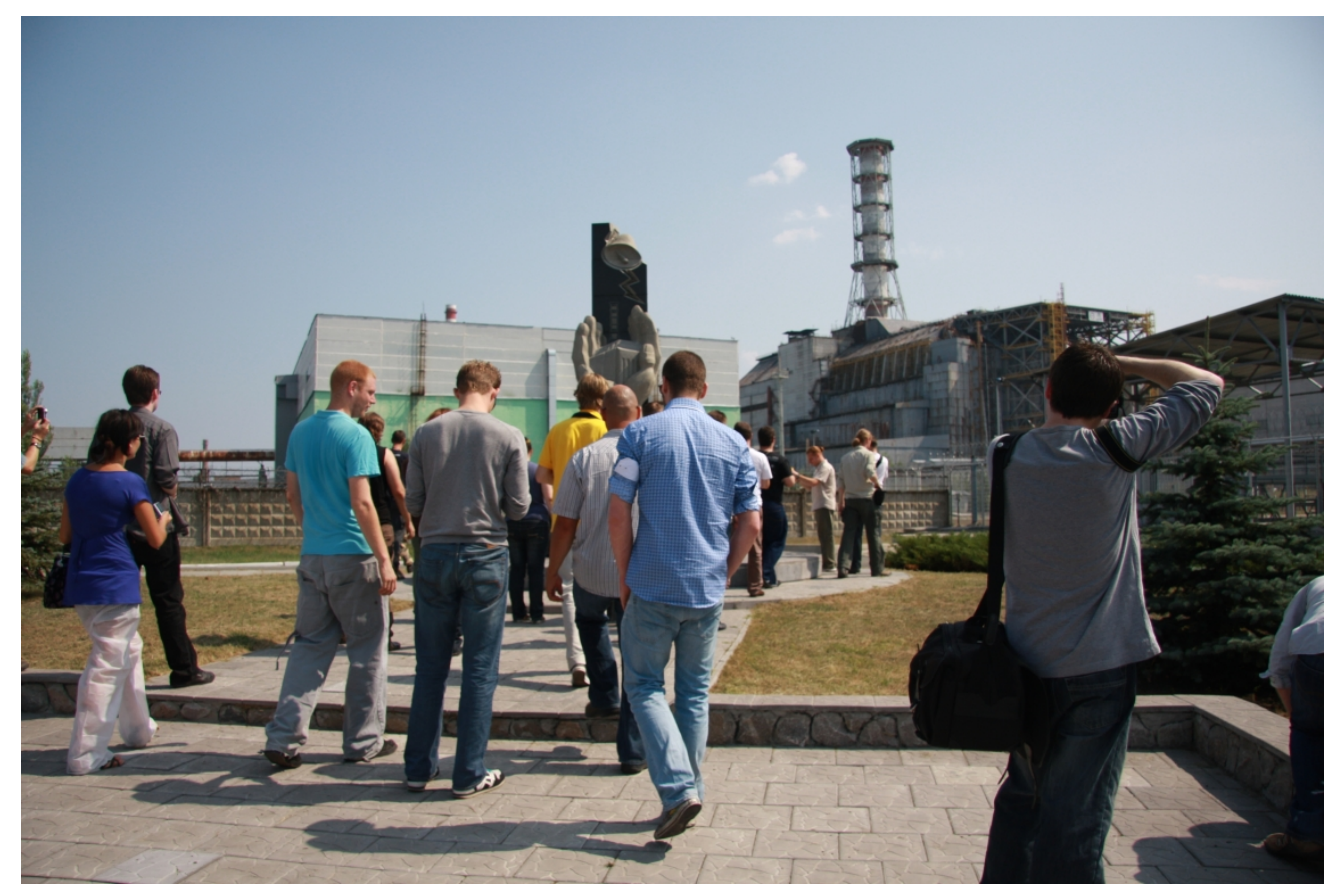

Reactor 4 and memorial.

$1371 \times 914 \mathrm{~mm}(72 \times 72$ DPI) 


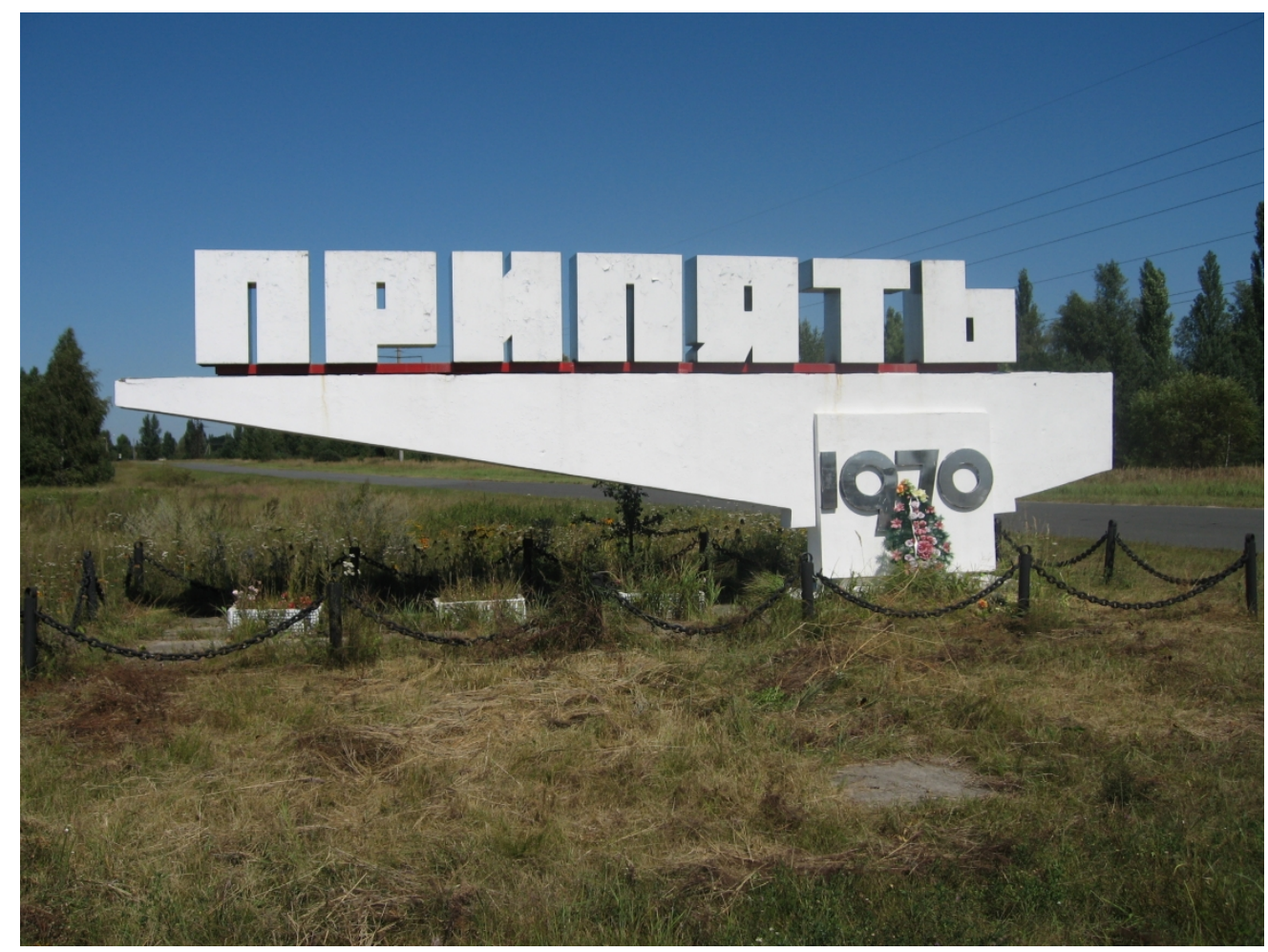

Sign on the road into Pripyat.

$288 \times 216 \mathrm{~mm}(180 \times 180$ DPI $)$ 


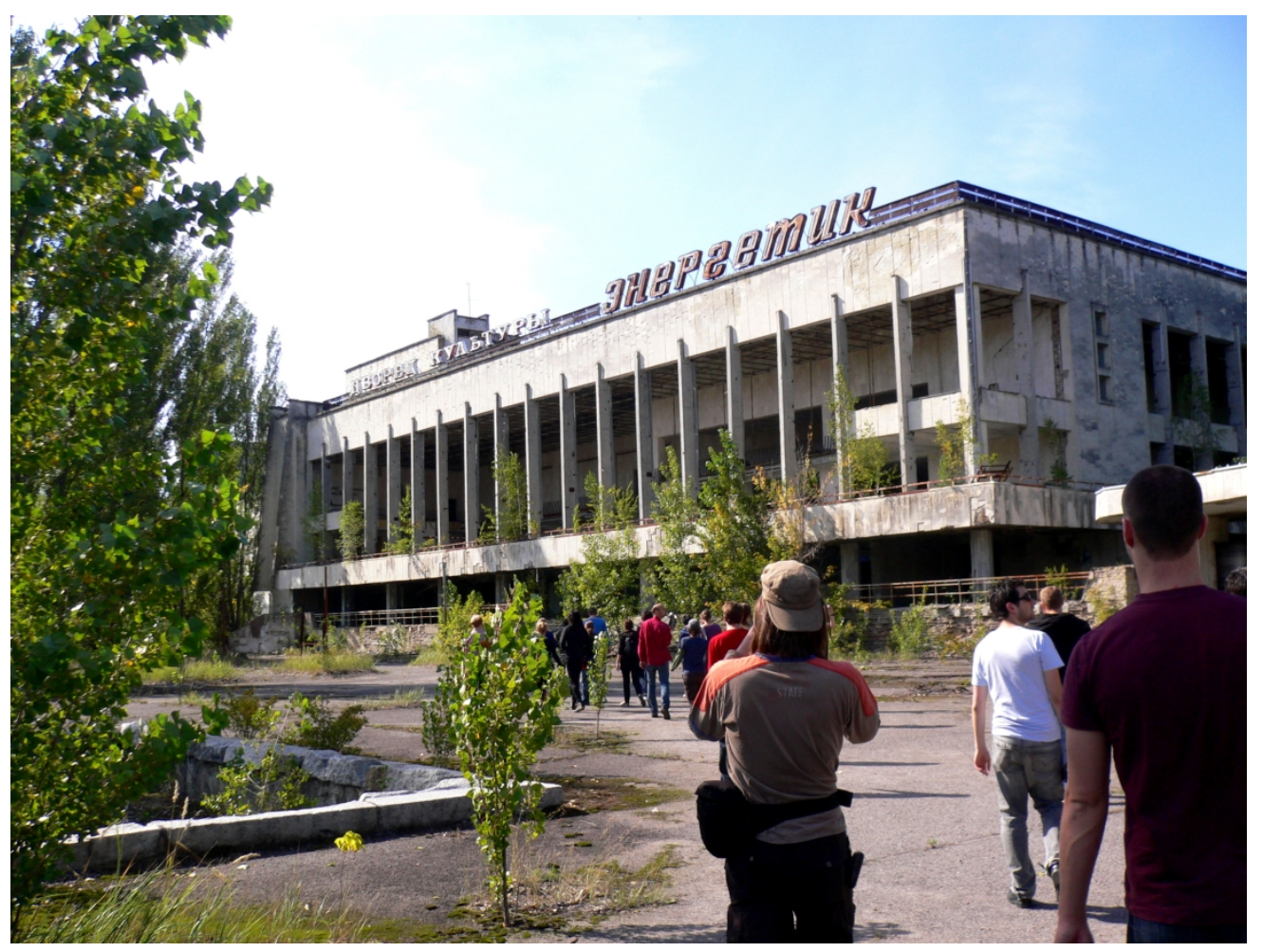

Pripyat's main square. 


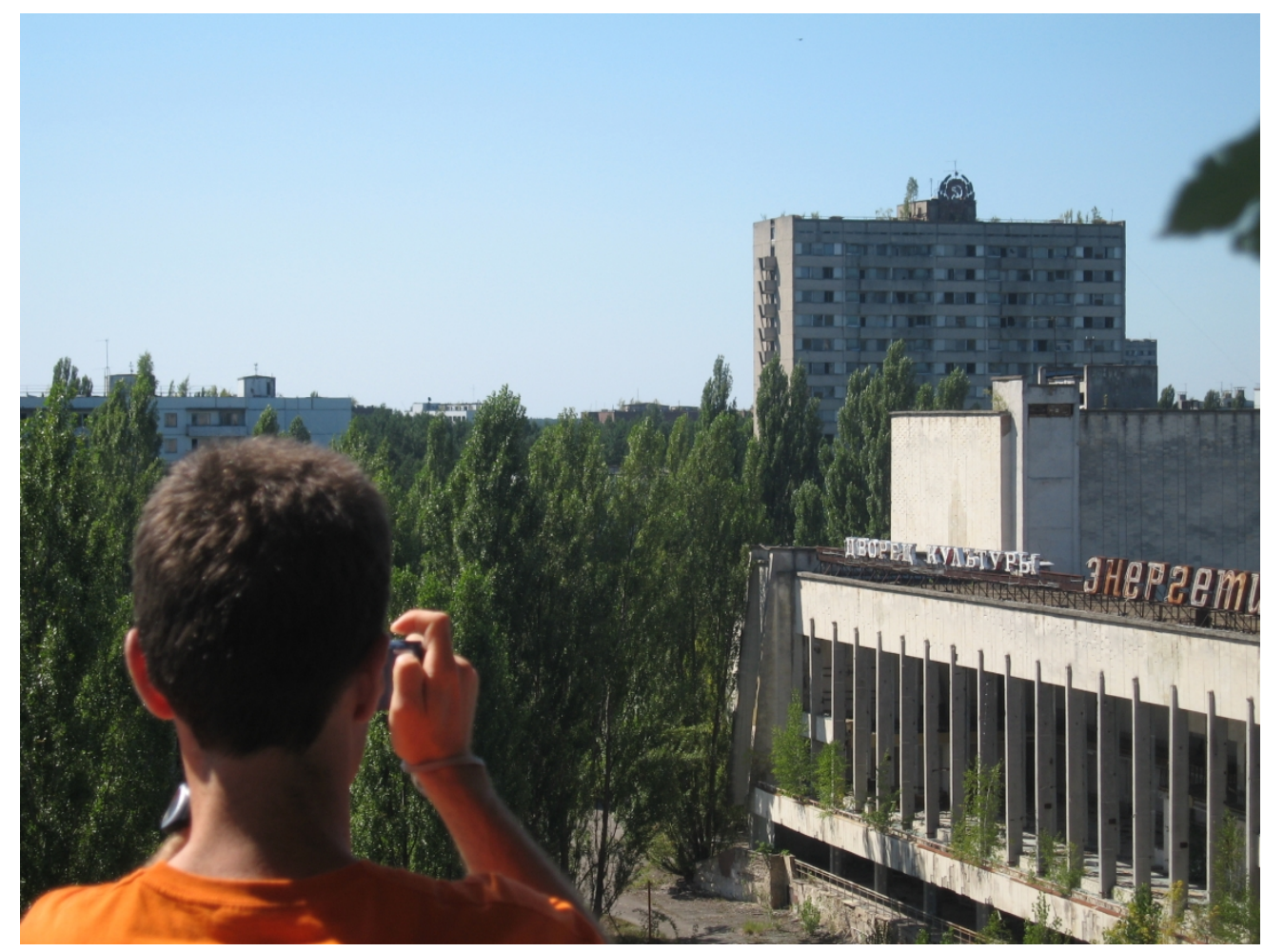

The view from the top of Hotel Polissya. $288 \times 216 \mathrm{~mm}(180 \times 180 \mathrm{DPI})$ 
Inside the school.

56

57

58

59 


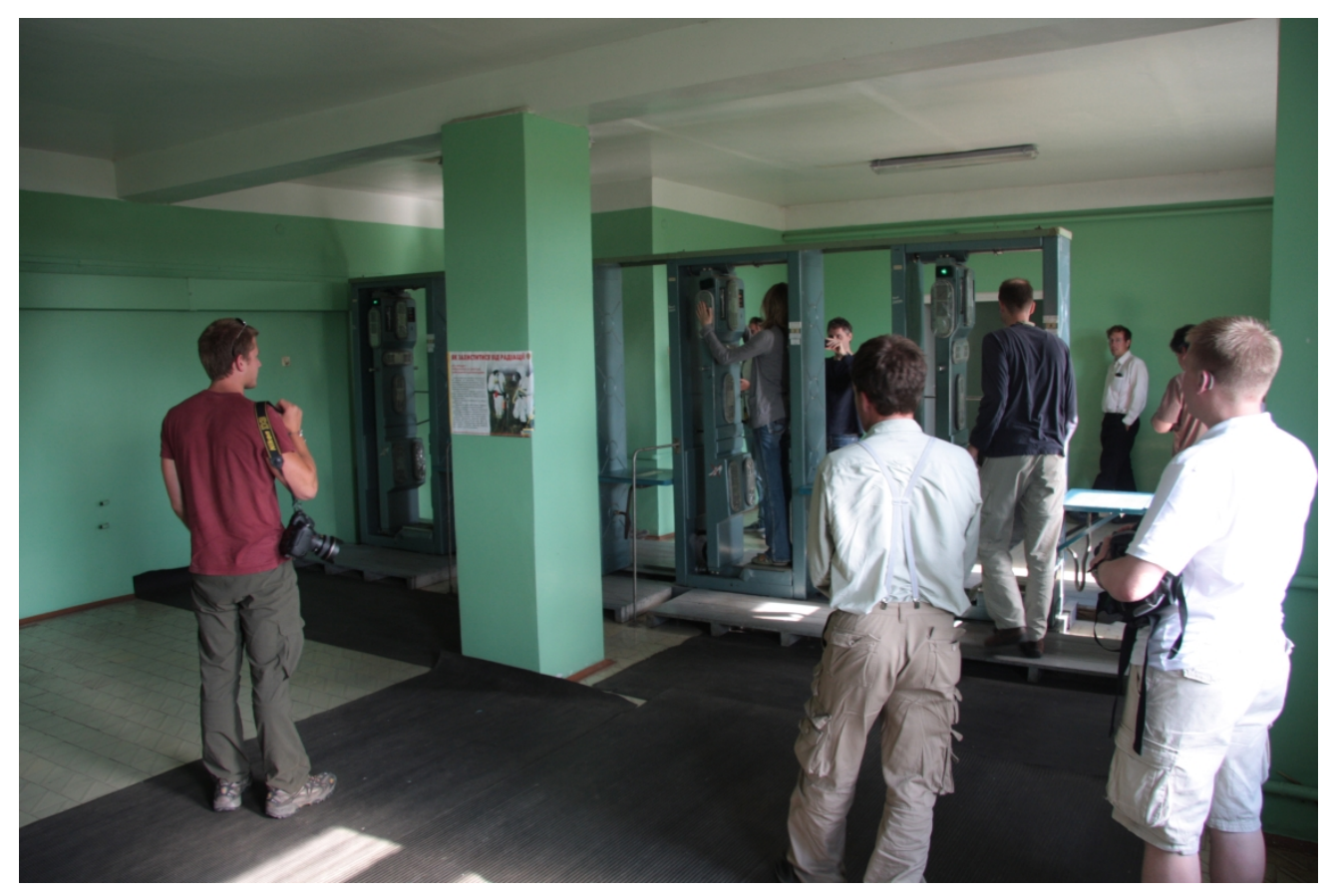

Leaving the Zone.

$1371 \times 914 \mathrm{~mm}(72 \times 72 \mathrm{DPI})$ 


\section{Introduction}

Image 1: The Chernobyl Nuclear Power Plant.

This paper theorises exposure through research in the radioactive landscape of the Chernobyl Exclusion Zone ('the Zone'). As isotopes decay and time passes, radiation is woven into the narratives of the Zone as it is seen, read and understood by tourists. Through tours, the Zone is understood through the historically and culturally contingent 'tourist gaze'1 informed by histories of Soviet Others, discourses of nuclear power and future imaginaries of post-apocalyptic urban ruination ${ }^{2}$ in popular culture. More widely, the Zone's landscape figures in political and cultural discourses of nuclear futures ${ }^{3}$ and the lives and bio-citizenship ${ }^{4}$ of those affected by the fallout. ${ }^{5}$

But, before being woven into narratives of this landscape, radiation is woven into the landscape in material ways as fallout: The decaying radionuclides create a future spectrum of contamination, from the short-half-life of iodine-131, measured in days, to decades-long half-lives for its cousins of ${ }^{137} \mathrm{C},{ }^{90} \mathrm{Sr}$ and ${ }^{241} \mathrm{Pu}$, and to half-lives of hundreds of years (and thus thousands of years of ongoing radioactivity) for other isotopes of plutonium and americium. These radionuclides, which were deposited unevenly by the 
winds and rain after the disaster, emit radiation as they decay which passes through air, landscapes and bodies, weaving them together. Absent from direct sensual experience, but attested to by the chirruping of the Geiger counter, in radiation we find an intertwining of embodied tourist subjects and landscape which cannot be romanticised as seeking to "get closer" to nature.

These material encounters with radiation whilst visiting the Zone do not take place through modalities of narrative, discourse or gaze, but through exposure; an embodied vulnerability to that which we cannot sense. Therefore, starting with questions of the construction, representation, interpretation and consumption of the radioactive Chernobyl landscape risks reducing radiation to questions of language and thought. With the aim to 'take seriously the world's own forces' ${ }^{6}$ this paper takes on the challenge of analysing, as an object of sociological enquiry, fallout and radiation as worldly force, with material, ionising properties.

In matters of the nuclear, the body must be understood as porous and transforming, as much a 'repository' for radiation as the landscape. ${ }^{7}$ With its focus on both the physical and subjective, the analytic lens of 'landscape' is useful for an examination of the nuclear ${ }^{8}$ in which 'the connection between place and bodies is often understood in terms of 
exposure, as contact between misplaced matter and flesh.' ${ }^{9}$ Therefore, this paper is aligned with recent work that researches and theorises landscape through processes, performances and corporeality. ${ }^{10}$ This work has sought to reconsider the assumed coherency and stability of landscapes ${ }^{11}$ and the subjects which walk in and gaze upon them, ${ }^{12}$ taking an anti-foundationalist approach by asking not what landscapes are or how they are interpreted, but how embodied subjects and landscapes co-produce one another. ${ }^{13}$ Merleau-Ponty's account of embodiment and perception has become a 'cardinal reference point' ${ }^{\prime}$ for this work in its rejection of dualism and epistemologies of distance. However, recent post-phenomenological writing in geography has questioned ontologies of co-incidence and co-production, in part for how they struggle to theorise alterity. ${ }^{15}$ Radiation's alien agencies offer a similar challenge, yet Merleau-Ponty's rejection of distance and his language of 'weaving' and 'intertwining' offer an appealing starting place for understanding radiation. Therefore, this paper uses radiation as an impetus to re-visit Merleau-Ponty's phenomenology in relation to these recent critiques.

This paper is structured around a series of vignettes. Taken from different trips, together they offer a composite account of a day-trip to the Zone from my perspective as a tour guide whilst 'learning on the job'. I identify three 'models' of perception within MerleauPonty's work; 'pointing', 'plunging' and the 'touching-touched'. Though a useful starting point, I show how radiation disturbs these models, and so introduce post- 
phenomenological critiques. 'Exposure' has occasionally appeared as analogy or metaphor in this post-phenomenological writing. In the Zone, exposure is the embodied encounter with ionising radiation, and so this paper interrogates this language of 'exposure' through an examination of radiation as worldly force. Where these writers have drawn upon writers such as Derrida ${ }^{16}$, Levinas ${ }^{17}$, and $\mathrm{Nancy}^{18}$, this paper brings the work of Irigaray into these debates. Drawing inspiration from Merleau-Ponty's various 'models' of perception, this paper develops 'exposure' as a model of subjectification, predicated upon an unwilled, unavoidable, passive and vulnerable exposure-to as (pre)condition of the subject. A relation-with, understood, via Irigaray, as inhabitationby which neither subsumes, nor distances, the indifferent forces of worldly Others.

The Chernobyl Exclusion Zone is a large area of northern Ukraine designated for its high levels of radioactive contamination as a result of the 1986 disaster. The ruins of Pripyat, in particular, have received popular attention; appearing as setting for Hollywood films and digital games. ${ }^{19}$ The Zone currently draws a few thousand visitors per year, mostly day trips from Kyiv. Sociological studies have most often focused on those living with the consequences ${ }^{20}$ and they highlight the importance of bodies and bio-materialities. In tourism studies, the Zone has figured as a site of industrial ruin ${ }^{21}$ and the sublime. ${ }^{22}$ 
This paper is based upon ethnography over 25 visits to the Zone whilst acting as a tour guide. The Zone is not managed for tourism; there is no script for the guides, no defined narrative. Guides understand their role as allowing visitors to develop their own interpretations. My own knowledge of radiation is a mixture of advice from those working in the Zone and independent research: I followed the weekly schedule used by those working in the Zone to avoid chronic exposure and received advice from guides about particular 'hot spots' to avoid. Published radiation safety advice helped me gain a sense of how to interpret the Geiger counter and monitor my exposure. Radiation safety and radiometry is stochastic, not predictive and a reactionary body of knowledge that often changes. ${ }^{23}$ Although I never felt particularly unsafe, I was never fully certain. thus, though in a position of authority, I was making sense of radiation alongside those I was also guiding. Moments when I inform visitors demonstrate this 'second hand' knowledge where radiation governs behaviour through radiometry, institutional responses and shared stories. $^{24}$

\section{Reactor 4}

\section{Spectacle}

Image 2: Reactor 4 and memorial. 
The minibus stops in direct view of reactor 4 and its sarcophagus. Here there stands a memorial (Image 2) and the guarded entrance to the construction site of the 'New Safe Confinement'. As visitors leave the minibus, I hold out my Geiger counter as it chirruping becomes more urgent. I explain that the proximity to the reactor and its rusting sarcophagus means the levels here are 3 to $7 \mu \mathrm{Sv} /$ hour depending on the weather, compared to $<1 \mu \mathrm{Sv} / \mathrm{hr}$ in Kyiv.

So, as the bus door slides open visitors' expectation and excitement is intermingled with trepidation. Visitors who head to stand by the monument and take photos will often stall half way, turning back, unsure if they have wandered too close. Others will not begin to walk forward until they are accompanied by a tour guide or another visitor wielding a Geiger counter, curious as to the fluctuation in readings. As visitors turn towards me, clearly hesitant as to what to do, I realise that I need to offer some guidance. I recount what I have heard from previous guides; I point towards the memorial, "the advice is not to stand any further forward than the memorial." I wave towards the edge of the road that lies between the memorial and the fence beyond, gesturing towards an invisible barrier "this is as close as we are allowed to get" I tell them. Radiation levels vary by temperature and wind, making this a radiometrically arbitrary delineation. It is defined more by a desire to avoid friction with the police, who have become somewhat zealous in their 
policing of the New Safe Confinement site. I do explain this to the visitors who ask questions about the radiation here, and I explain that this area has been heavily cleaned to allow for the decommissioning works, and we will see much higher readings later. A yearly dose, working here at $7 \mu \mathrm{Sv} /$ hour would be a high dose compared to most nuclear workers, but is still below the $20 \mathrm{mSv}$ / year set by the UK HSE ${ }^{25}$ and is a tiny fraction of the highest estimated levels of over $200 \mu \mathrm{Sv}$ /hour during the liquidation. Nevertheless, we avoid the most heavily contaminated areas and visitors are warned against smoking or eating, so as to avoid internal contamination. As I am explaining this to a handful of stragglers, most visitors move to take photographs. Visitors stand at a distance from the sarcophagus, taking in the spectacle of the scale of this edifice and the scope of the disaster it silently attests to, Geiger counters are handed round as props for the photos.

\section{Distance: Pointing}

I point to the sarcophagus, and the chimney stack of reactor 4 which emerges from it. As I point to it, at a distance, I explain that they will soon start removing this for the New Confinement; very carefully, piece by piece, so as to disturb as little as possible the highly radioactive fallout settled on it. As I point to reactor 4, at a distance, a momentary breeze goes past and my Geiger counter, now in the hands of visitors as a prop for their photos, chirrups a little more urgently. 
Distance figures prominently in the history of landscape epistemology, both figuratively and literally. For Cosgrove landscape refers not just to a given region or view, but is a 'way of seeing'26: A particular historically and politically situated epistemology of sight borne out of perspectival, survey techniques which understands landscape as geometric object and the viewing subject as surveyor-at-a-distance, thereby arguing for greater examination of the ideologies of vision implicit in geography. ${ }^{27}$ By evidencing that landscape's epistemological history aligns with dualistic understandings of perception Cosgrove identifies the legacy of a 'spectatorial epistemology' which - Wylie summarises - supposes 'an external pre-given reality observed and represented from a detached position by an independent perceiving human subject. ${ }^{28}$ Phenomenological and embodied accounts of landscape have sought to challenge this legacy.

In Phenomenology of Perception (Ph.P), Merleau-Ponty describes the gesture of 'pointing-and-naming' and offers this as a critical model of dualistic approaches, which; presupposes that the object, instead of being approached, grasped and absorbed by the body, is kept at a distance ... subsumed under some category. ${ }^{29}$ 
In this model of pointing, a subjects' actions are understood to construct the world (through discourse and language) and produce objects for perception (by defining them as concepts / objects in thought). Such spectatorship epistemologies understand knowledge of landscape as something "both produced by and located in a detached, observing subject" 30 often examined through questions of discourse and language. Merleau-Ponty rejects this model of pointing, based upon distance, as being a ‘proprietary' epistemology.

Guiding and photographing may seem fine examples of spectatorship. However, as I point to the reactor, the Geiger counter attests to the radiation which weaves together gazing tourists and Reactor 4 across this distance. Following Merleau-Ponty's rejection of distance as founding principle is not just theoretical, but demanded by the landscape's material forces. Pointing at the sarcophagus and reactor, indicating invisible boundaries, reading the $\mu \mathrm{Sv} / \mathrm{h}$ reading on the Geiger counter's LED screen, and posing for and taking photographs may name radiation, construct it as a social, cultural, touristic object of thought. In these ways, tour guides and tourists socially construct knowledge of radiation and landscape, but the goal of this paper is to engage with the more-than-representational ${ }^{31}$ aspects of radiation: To not begin with these constructing 
practices, for they are secondary to radiation's capacity to ionise our cells, and the capacity of embodied subjects to be irradiated.

\section{The Red Forest}

\section{Gesturing towards the invisible}

Image 3: Sign on the road into Pripyat.

We head back to the waiting minibus and our driver circumnavigates the powerplant complex. Soon we enter a large crossroads, at one junction stands the iconic Pripyat entrance sign (Image 3). Before everyone disembarks, I repeat a warning given earlier; avoid the grass verges on the side of the road as the radioactivity levels are greater there due to the run-off from the road. The short break from the hot minibus is welcome but, apart from the photo-opportunity of the sign, the view is unprepossessing. I am soon confronted by some idle and bored visitors, and realise it is my job to engage them. I reach for the only thing I know about this view, and I ask visitors to look towards the forest. I point westward and gesture past the railway and towards the distant treeline. "Those trees over there" I declare out loud "are known as the Red Forest". 
The Red Forest, I explain, is not, actually, red. At least, not any more. The Red Forest (Krasnyi Lyes) is known as such for the period immediately after the 1986 disaster; with the winds blowing west, the fire at Reactor 4 deposited an invisible payload over the nearby pine forests. As the radioactive fallout killed off the trees, they turned a reddishbrown colour. The dead wood posed a fire hazard, so the trees were bulldozed and buried, but the forest remains the most radioactively contaminated area in the Zone, indeed anywhere on Earth. It is new pine trees, now maturing, that I point to from the side of an otherwise fairly dull spot at a quiet road junction of northern Ukraine. The forest was once red, a moment in time of cultural significance, and so remains Red.

Whilst the naming of the 'Red Forest' may reproduce this landscape as radioactive, the worldly forces of radiation will perpetuate even when the name 'Red Forest' is forgotten. Knowledge of the radioactivity of the 'Red Forest' is, for visitors here, a product of my pointing-and-naming, but its 'redness' - the radioactivity that remains - should not be thought of as so: This is a redness transmitted not by pointing towards it, but reaching out towards us through the air as $\gamma$ wavelength photons (and its subatomic cousins $\alpha$ and $\beta$ ). This quality of red is not a feature of a landscape seen. Radiation has no need of our pointing and naming, no need to be represented, in order to ionise bodies. What is needed - and what I will show that exposure offers - are the theoretical tools for sociological inquiry to engage with worldly forces that exceed representation. 


\section{Plunging \\ 'Pointing-and-naming' serves as a model for the construction of the world through discourse and language, but a consideration of radiation's weaving of landscape and bodies together demands a rejection of models based upon distance. Merleau-Ponty offers the verb 'to plunge' as an alternative model; 'to see the object is to plunge into it'. ${ }^{32}$ Or, as in this passage:}

The sensible gives back to me what I had lent it, but I received it from the sensible in the first place. Myself as the one contemplate the blue of the sky is not an acosmic subject standing before it, I do not possess it in thought, I do not lay out in front of it an idea of blue ... I abandon myself to it, I plunge into this mystery, and it "thinks itself in me." I am this sky that gathers together, composes itself, and begins to exist for itself, my consciousness is saturated by this unlimited blue. ${ }^{33}$

This is in opposition to a model of pointing, which would give the sky its blueness by naming it as such (thereby making its blueness a property of thought and language). Instead, to say the blueness of the sky 'thinks itself within me' is part of Merleau-Ponty's project which denies distance and dualism, weaving together subjects, perceptions, bodies and landscape. Against metaphysical and epistemological distancing Merleau-Ponty 
offers a sustained consideration of the subject as first a body-subject and, therefore, necessarily part of the 'tightly woven fabric' of reality. ${ }^{34}$ In the Zone it is radiation that weaves together subjects and landscape. Thus, despite being models of perception, and radiation being extra-sensory, Merleau-Ponty's language of plunging, intertwining and weaving offers a useful grammar and starting point for a consideration of exposure.

I'm running out of things to tell or show visitors here. Despite my previous warning, I take two steps (I 'plunge') into the tall grass to evidence the contamination, and the previously clicking Geiger counter rises to a cacophony. An auditory spectacle that guides sometimes offer at various localised 'hot spots'. In 'plunging', Merleau-Ponty offers a model of landscape-subject relations that is one of co-becoming. However, it is an abandonment-to which, Grosz notes, is predicated upon a willed and cultivated openness to the world. ${ }^{35}$ Even in plunging, the subject remains the central figure which initiates relations. But the openness that is exposure is not willed: despite walking into the grass verge, Geiger counter in had, I neither have to hear and see (via mediating technology) nor know of the mechanisms of ionisation and wave-particles to have been irradiated.

Standing here, just a metre or so away from the road, with an un-prepossessing view of a forest like many others, I point the Geiger counter reading out to the on-looking visitors. 
A reading that will far exceed anything else they will see today, even by Reactor 4 itself. I think I'm safe. The readings aren't beyond what I think might be dangerous, at least for this short moment. I nervously switch the LED readout to the cumulative count for today; it's below what I think is a safe limit, albeit a little higher than it usually is by this point in the tour. Ionisation of my cells occurred before (and despite) the increasingly urgent crackling of the Geiger counter, which only offers, for perception, an after-the-fact account of my having already been 'plunged'. Exposure is only knowable after-the-fact, and only partially, uncertainly and unsettlingly.

Within landscape studies, Wylie notes a focus on practices (walking, looking, cycling, cultivating etc.) which, when drawing upon Merleau-Ponty and similar ontologies of cobecoming and co-presence, leads to an empirical focus on practices of 'bringing-intopresence ${ }^{36}$ or making visible. Harrison argues that the problem with Merleau-Ponty's 'plunging' in Ph.P, is that it 'preserve[s] and reinforce[s] the primacy of purposeful activity in the genesis and maintenance of meaning'. ${ }^{37}$ Noting that doing and action, specifically 'bodies-in-action' have become the central figure of research. In the general 'practice turn' passivity remains untheorized, unexamined and pathologized. ${ }^{38}$ Tall grass almost up-to my knees, the Geiger counter now a cacophony of clicking and chirruping. I tell visitors that we'll see other examples of how readings can change substantially over a short distance, and how this does not always map onto any obvious visual features. 
Radiation is never made visible, never grasped by the senses. Even the stratified sampling methods behind environmental scientists and workplace 'annual dose' limits do not fix exposure and radiation's effects as deterministic. I may know radiation with the Geiger counter, with passed-down knowledge and health-risk literature, but these are all incomplete, uncertain attempts to know the invisible. Not that many visitors ae still interested in my attempts to fill this time with my description of the Red Forest or this demonstration of radioactivity, and I feel a little foolish, knee-deep in this grass

I have chosen to stand here in the grass, and the tourists have chosen to visit the Zone. There is a social positionality to tourism that differs from other exposed populations, such as those living near the Zone or with the ongoing effects of the disaster. I may know I will be exposed (more) when I decide to enter the grass verge, tourists may know they will be exposed (more) when they chose to enter the Zone. But radiometry doesn't afford precise predictions; exposure is only ever known via Geiger counters, dose recordings, only as having-been-exposed, and then only partially, uncertainly. This is not to deny the socially positioned agency that led visitors here, but, rather, to affirm that we are enmeshed in relations with landscapes, materialities and worldly forces, in ways that we cannot fully represent and know. 
In this way, exposure, as with vulnerability, is socially differentiated and induced; but it is also an existential condition. ${ }^{39}$ Thinking exposure requires a rejection of models of subject-landscape relations that centres the agential, embodied subject as that which initiates relations with landscape. Whether 'pointing-and-naming' the Red Forest, or 'plunging' into the grass verge, these acts cannot be thought of as initiating relations between landscapes and embodied subjects. This is not a plunge that a subject initiates, nor a cultivated orientation to the world; exposure is fact of the unavoidable openness-to that is embodied being. The extra-sensory nature of radiation requires an account of corporeality that is radically unwilled.

\section{'Touching Touched'}

It is clear that Merleau-Ponty's 'plunging' is too solipsistic and wilful a model, for it is the subject's action which 'unifies' subject and world. Indeed, recognition of this is given in the working notes of the posthumous The Visible and Invisible (TV\&I), which state 'The problems posed in Ph.P. [...] are insoluble because I start there from the "consciousness""object" distinction'. ${ }^{40}$ This later work suggests a very different conception of subjectivity and meaning, ${ }^{41}$ found the 'reversibility of the flesh'. Based on the model of an individual clasping their hands together, in the 'touching touched', the hands are simultaneously subject (toucher / perceiver) and object (that which is touched / perceived). The hand 
'takes its place among the things it touches, is in a sense one of them.' ${ }^{42}$ Merleau-Ponty's move is to use this fleshy model as a model for vision, and for sensing things other than oneself. In doing so, rejecting both distance and solipsism.

The 'touching-touched' offers a model which begins with a 'phenomenological collapse of self and world' ${ }^{43}$ The embodied subject is always, already, part of the world it inhabits: A thing amongst things wherein 'the subject is implicated in its objects and its objects are at least partially constitutive of the subject. ${ }^{44}$ Ontologies of co-presence and coimplication, such as the 'touching-touched,' have been central to work which has argued against the presumed existence of a stable subject a priori standing apart from the landscape-object, and instead understands landscape as implicated in processes of subjectification. This is not just a co-production wherein subjects construct landscapes (with cameras, Geiger counters, through discourse etc.) and vice-versa, but ontological co-constitution wherein 'landscape' refers to the 'simultaneous gathering and unfurling, through which versions of self and world emerge as such. ${ }^{45}$ Vision becomes understood not as a looking-at but a seeing-with and landscape is not something seen, nor a 'way of seeing', but 'the materialities and sensibilities with which we see.' 46 These materialities are understood as forces and energies: Landscape as an ongoing, animated becoming. ${ }^{47}$ Radiation is part of these worldly materialities, potencies and forces, through which embodied subjects emerge as gazing tourists and irradiated guides. 


\begin{abstract}
Passivity
In order to collect data on the effects of radioactive soil contamination some saplings have been planted in rows in a clearing at the edge of the Red Forest. Responding to Heidegger's 'forest clearing' Irigaray argues that vision requires the materialities of air, as medium for photonic light. ${ }^{48}$ Indeed, there is something of the nuclear to Irigaray's reminder:
\end{abstract}

The clearing of air is a clearing for appearing and disappearing, for presence and absence. At least that is how one can - one could? - think of it when forgetting the materiality of air. The power of which materiality technophysics assumes the responsibility of recalling. By means of the effect produced by the splitting of the atom, for example... ${ }^{49}$

The Geiger counter has risen to a continuous crackle; an audible testament to Irigaray's reminder of a world not emptied, awaiting presencing, but filled with the materialities of air, light and radiation. Drawing from Merleau-Ponty, Irigaray writes; 'The seen is in some way active, and the seeing partly passive to the extent that seeing corresponds to being touched by something or by someone - first of all by light waves. ${ }^{50}$ In response to landscape phenomenologies based upon the 'touching-touched,' exposure requires that 
we recognise that it is not the subject that initiates the touching. A sense of this can, in fact, be found in the working notes of $T V \& I$ which state 'it seems to us that perception forms itself in the things themselves -- Activity $=$ passivity'. ${ }^{51}$ From this, we can understand radiation as active materialities which touch us as they ionise. With the help of Irigaray, there is a more radically passive sense of the subject to be salvaged from Merleau-Ponty's work which would avoid the residual solipsism of 'plunging' which remains in the touching-touched.

The exposed body-subject is passive, but, rather then pathologising passivity as deliberate inaction, Harrison instead argues for passivity to be understood as essential pre-condition. The self 'as always already affected beyond its capacities to know and to represent'. ${ }^{2}$ Although the empirical materials here are embodied practices, exposure nevertheless demands the same recognition of an orginary passivity, prior to, and precondition for, and action. What is at stake here is how we understand the preconditions, the grounds, of subjectification, of the self and, in turn, what relation this entails with landscape and worldly Others. The touch and touching of exposure is not actively initiated by the subject. This is a passivity in relation to affective materialities and worldly forces as the foundation of action. Exposure understands the embodied subject as both active and passive, or, more precisely, passive in its activity. 


\section{Excess}

Exposure names a relation with the world. But what of relationality when the phenomenological subject has 'already been decentred amid the giveness of the world and so cannot form the foundation or origin of that relation', ${ }^{53}$ The response of postphenomenological approaches has been to re-consider alterity and Otherness, something which radiation's alien agencies also demands. Within this work 'exposure' has been used to describe this relation with alterity. In Wylie's paper on memorial benches, which attest to absent others but fail to presence them, this 'gap, fracture or absence [...] equally and always entails an openness, an originary exposure to externality and alterity.' ${ }^{54}$ Exposure as a pre-reflective relation also appears in Harrison's writing on passivity, in which 'passivity indicates a radical openness and exposure to alterity' ${ }^{55}$, prior to consciousness. Again in Simpson's writing on intersubjectivity where, after Nancy, 'the subject ... is from the start exposed to what it is not and therefore fundamentally impure. ${ }^{96}$ In each of these three accounts, exposure names a foundational relation-with alterity which is presubjective. The use of 'exposure' in these examples supports the assertion that the exposed body-subject is a necessarily, unwilled (not cultivated) openness-to. We may become aware of our exposure - via, say, a Geiger counter - but exposure is the relation 
with worldly agencies that exists prior to perception and, indeed, whether-or-not we become aware.

This means starting from the "non-coincidence of self and world, ${ }^{57}$ refusing the 'phenomenological fusion of self and world.' For Wylie, the power of memorial benches is the manner they 'withdrew the entire scene into absences, distances. ${ }^{58}$ A similar sense can be found in Harrison's writing wherein the subject 'comes to itself through and as the withdrawal of alterity' ${ }^{59}$. The language of absence, distance and withdrawal in postphenomenology differs from the distances of spectatorship epistemologies in that it is not a return to an a priori subject. This is a body-subject that does not pre-exist its relations, but is composed 'in and through its relations with a material-agent world.' ${ }^{60}$ Exposure requires that we recognise that the relations through which the subject emerges cannot be limited to those which are sensible, knowable or representable. Nevertheless, the use of exposure to name this foundational relation-with sits uneasily with notions of absence, distance or withdrawal. In basic empirical terms, the gamma rays and beta particles that weave porous bodies and landscapes together are not in withdrawal. Theoretically, to figure radiation as absent or distant from perception is to describe it in terms of is (non)existence for us. Though based on these post-phenomenological accounts of subjectivity, exposure offers an alternative language; that of excess. 
Radiation is not an 'absent presence'; radiation is far too present. It exceeds the perceptual capacities, it exceeds our representational capacities and efforts to construct it as knowable and it exceeds bodily capacities for self-healing. Exposure is a relation with worldly agencies that are difficult to frame as a live-liness of vitalism. Yet neither is radiation straightforwardly destructive; ionising energy excites the cells of landscapesubjects with a certain creativity.

I step back from the grass, onto the road, and once again nervously check the dosage total for the day so far on my Geiger counter. I make a mental note to wash my shoes and trousers the moment I get back to the apartment. Irigaray's reminder of the touch of light asks us to think of the materialities which hold together seer and seen. The decay of radiation, though not seen, are amongst those wasting processes of material that is, nevertheless, agential: 'both holding together and ripping them apart.' 61 Contra to Wylie's geographies of love which through absence and withdrawal, 'will tear us apart', ${ }^{62}$ it is the abundances, all-too-present, worldly, creative energies; the excesses of radiation's ionising photons, electrons and protons, which threaten to 'rip us apart'. Exposure requires that we think of the worldly forces, agencies and materialities - through and in which the subject is composed - as a world in excess: Exceeding our senses, our 
capacities to know and name, and capacities for self-healing. Worldly agencies, forces and materialities, such as radiation, exceed our perceptual, representational and bodily capacities. This language of excess builds upon these post-phenomenologies of subjectification, but offers an alternative orientation towards worldly materialities, forces and agencies. Exposure requires a recognition of a more troubling and threatening foundational relation with alterity as a worrying and unsettling excess, experienced as vulnerability.

\section{Pripyat}

\section{Vulnerability}

Image 4: Pripyat's main square.

We head back to the minibus, and I'm relieved to not have to find anything else interesting to say or demonstrate about this unprepossessing stretch of road. We drive for a few hundred meters and encounter a small checkpoint where a solitary police officer waves our driver past. Old apartment blocks can just be made out behind the trees as we pass them. I explain that this was once the main boulevard 
into Pripyat, the town which housed the workers for the plant, now crowded out by trees as the Red Forest expands eastwards.

\begin{abstract}
We pull onto the main square. Only by looking up, to see the tops of the taller apartment blocks which sprout above the treeline (Image 5), is there clear indication this used to be a town of fifty thousand inhabitants. Pripyat is not a manged site. With no script for guides our main concern is safety: Sticking to known routes within and between buildings, avoiding areas where roofs or floors had fallen in.
\end{abstract}

Image 5: The view from the top of Hotel Polissya.

In the 'touching touched' model, touch and sight become intertwined. In Pripyat, touch and sight are similarly experienced together, but in a less harmonious manner. A site of intrigue and fascination, visitors are nevertheless hesitant in their movements. Remnants of past lives can be found throughout Pripyat. But this is not a museum; artefacts are often strewn across the floor. These remnants invite 'hands-on' engagement, to pick them up, get a closer look. But this draw is tempered by a hesitancy, uncertainty; that these items might be unsafe. An examination of picture books in the library is done with hesitation; photographs are taken from a distance, pages are carefully turned with shoed feet rather 
than bare hands. An old music room (Image 6) with a ruined piano invites tentative key presses to just see if it might still work; hands stretch out, stopping at the last moment, retracting. Visitors wonder aloud what the overturned pile of posters might display, but no one moves to turn them over. Visitors shrink, drawing into themselves when navigating narrow corridors. This avoidance of touch happens without any prompting from guides. This is not the foundational distancing of spectator and spectacle, but are rather attempts to actively create distance where there is none. A response to the vulnerability that is exposure, which impinges on visitors' sense of bodily coherency. In the Zone it is visitors themselves, not worldly Others, who attempt 'withdrawal' as the avoidance of touch and careful, considered steps comprise the bodily comportment of reflexive vulnerability in Pripyat.

Image 6: Inside the school.

Where Harrison suggests sleeping bears witness to the 'intrinsic vulnerability and finitude of corporeal life,' 63 the same intrinsic vulnerability can be found in the conscious, embodied actions of the visitors who withdraw from the invitation to touch and handle. Where exposure is the foundational, passive, relation with worldly others, vulnerability is its modality. This requires an understanding of the subject as initiated by a (complex) world which exceeds the subject's capacities. ${ }^{64}$ The 'touching-touched', however, falls 
short of this. Merleau-Ponty states that 'The flesh of the world is not self sensing (se sentir) as is my flesh - It is sensible and not sentient — I call it flesh, nonetheless ... in order to say that it is the pregnancy of possibles' ${ }^{65}$ Holding something in reserve for the sensing subject, unwilling to extend agency to the non-human.

Much of Irigaray's critique of Merleau-Ponty is in the form of mimesis; adopting the language and position of his writings to develop a critique by 'thinking against him within his terms' ${ }^{66}$ Irigaray's critiques of Merleau-Ponty in An Ethics of Sexual Difference ${ }^{67}$ are the most well known, but I argue that Elemental Passions ${ }^{68}$ may be read as a response to Merleau-Ponty, even if the intended recipient of this antagonistic love letter is not named:

I gather you up in this place that I am for you. I contain you, whole, in this envelope that I am - for you. In this way I am able to keep you and you are able to remain in me. And I can return, restore you to what you are, I have this power. You even left me this power on condition that is serve to rediscover you, reconstitute you. ${ }^{69}$

Here, Irigaray echoes the way in which the touching-touched of the flesh is not reciprocal, but, rather, proprietorial or appropriation. As Merleau-Ponty states; 'the sensible gives back to me that which I had lent it' ${ }^{70}$ The reversibility of self / world is 'some repetition of a prenatal sojourn' ${ }^{71}$ wherein, 'the flesh' is of the subject, from which the world-asperceived emerges. The touching-touched of the flesh, Irigaray writes, is 'an enclosed 
world where the intertwining remains between himself and himself, between himself and a world which is already situated within himself. ${ }^{72}$ The 'flesh of the world', Grosz notes 'remains isomorphic with the subject', ${ }^{73}$ offering only mirrors for his sensibility. Because of this constitutive forgetting of the Other the 'touching-touched' figures perception as conception, ${ }^{74}$ remaining just as proprietorial as 'pointing-and-naming'. Irigaray's mimesis offers a vocalising of a world, which is present but unrecognised; the forgotten (maternal) Other, which is permitted no Otherness even as it is co-opted; a reminder of forgotten foundations.

Irigaray's reminders of air, light and atomic, forgotten Others serve to disrupt phenomenological fusions of self and world. Radiation and worldly forces do not await to be enrolled in the self-actuation of the subject; they remain Other. Not in withdrawal, also not serving to (re)constitute the subject. Here Colls notes Irigaray's important affirmation of the un-reachability of unity / completion of self. ${ }^{75}$ Exposure serves as a sublime reminder that 'we are never in some way definitively born as forms, never incarnated in an unchanging manner. ${ }^{16}$ Whether it be visitors who withdraw into themselves and decide to avoid touch, or the realisation that, in deciding to 'plunge' into the grass verge for my demonstration, I have already been plunged. Exposure, when experienced as vulnerability, is the reflexive realisation that we are always already intertwined with worldly Others. Both 'the plunge' and 'the touching-touched' offer a 
subject which, in opening-up onto a world, becomes completed by it. As an alternative model, exposure proposes that this opening-up to the world is unwilled (and even despite our best efforts) and which, in this opening-up, I am not completed by the world; I am undone. In the all-too-present excess of radiation I am not reconstituted, but reminded of my incompleteness.

\section{Relation-with as inhabitation-by}

Rather than landscape and subjects being co-produced, emerging from a shared source, radiation haunts phenomenological models as a forgotten, yet constitutive Other. We have seen some of the uses of 'exposure' in recent post-phenomenological work as that which 'inspires, holds and binds the subject in relations which it does not and did not choose and which lie before and beyond any of its abilities to comprehend conceptualise or represent. ${ }^{977}$ But radiation shows that this turn to exposure to reconsider alterity should not be used, as it has been, to name a 'relation with an exterior' or a subjectivity which is 'composed from outside. ${ }^{978}$ The addition Irigaray offers here is that the constitutive Other is not external to the unified / unifying subject. 
Recognising, in exposure, a bodily susceptibility 'to the forces-filled materialities of the world'79 requires a rejection of logics of both self / presence - Other / absence and that of any togetherness, holism or isomorphic co-incidence. For Irigaray:

Our body is not only set down or situated in space, placed side by side with other bodies, or other things. It is also intertwined with them, and interlacing of those within it. ... But this is not simply due to the fact that it is a body; it is rather because it always is in relation with. And that which philosophy lacks, even more than a thought about the body, is a thought about our bodysoul as being essentially relation-with. ${ }^{80}$

Irigaray mimetically repurposes the language of 'intertwining' to offer a conceptualisation of the body-subject as always in relation, but which is never completed of unified by those relations. Exposure names a relation-with that precedes any singular entity that might be called a subject, a relationship with Otherness (unwilling, open, passive, vulnerable) that is the very precondition for the subject.

The final move which Irirgary offers is the mode of this relation. Rather than the embodied subject and the world as one whole; of the same flesh, Irigaray writes of inhabitation: 


\begin{abstract}
My inner space is ... inhabited in multiple ways, and the manner in which I look cannot be reduced to the mere perception of the visible external to me. I co-look with that which already inhabits me, outside all representation. ${ }^{81}$
\end{abstract}

This inhabitation-by does not suggest a proprietorial relationship, but a foundational coexistence. ${ }^{82}$ The vital move here is that, far from an occupying 'dwelling' which figures landscape as passive abode, embodied subjects are themselves understood as dwellingplaces. Being is to be inhabited-by, prior to all representation, awareness or perception. Again the working notes of $T V \& I$ counters some of the limitations of the opennesstowards:

In reality there is neither me nor the other as positive, positive subjectivities.

There are two caverns, two opennesses, two stages where something will take place-and which belong to the same world, to the stage of Being. ${ }^{83}$

These notes also include reference to the body-subject as 'hollow' and 'abode' for the world. In Irigary's mimetic critique which serves as reminder of the constitutive forgetting of the Other which inhabits body-subjects, we find tools to salvage a more radical potential in Merleau-Ponty's phenomenology.

Lorraine summarises Irigaray's body-subject as 'living in a world that incessantly impinges upon us, and any self that we are able to stabilize out of this ever-changing 
movement of which we are but a part is completely implicated with what surrounds us. ${ }^{184}$ Visitors take photographs with the Geiger counter, are drawn to remnants of past others; a fascination always tempered with a simultaneous withdrawal, hesitancy, avoidance. These are observable actions in response to uncertainly-known, but present and excessive, worldly forces. We must therefore understand agency in these terms; moments of stabilisation of the subject, but which do not achieve distance, do not extract embodied subjects from their enmeshment in a world that exceeds them. Or, drawing from Vasseleu's reading, an inability of the subject to withdraw; instead of a focus on perception or brining-into-presence, exposure understands the body-subject as 'not reducible to what it experiences and is equally unable to withdraw itself from anything that it experiences. ${ }^{85}$ This is a body-subject which is perpetually incomplete and vulnerable to that which exceeds it. Through hesitation, through after-the-fact boundary negotiation we find a subject which 'strives' 'in response to the anxious unpredictable present 'nonpresence' of alterity. ${ }^{\text {}} 86$ Exposure, as inhabitation-by, is an alternative to both dissociation and distance and gathering and presencing./ Exposure offers a model of the body-subject which is founded upon an originary passivity; an unwilled openness, a 'cavern' for worldly forces in excess of our capacities. Exposure is a model of subjectification that is not just another means of figuring subjectification as a process of emergence; exposure is the simultaneous emergence and unravelling of the subject. 


\title{
Exposure
}

Image 7: Leaving the Zone.

\begin{abstract}
After a long day in the Chernobyl Zone, the minibus takes us back to the main checkpoint at the Zone's border. Tired, but chatting excitedly about the day just gone, we are directed into a small out-building containing a bank of body scanners (Image 7). We each go through the scanners, adopting the posture as instructed, followed by a dull thunk as the radiometry equipment engages, followed by a small light which deems us safe. Some visitors seem dubious, unsure whether to trust these dated machines with minimal feedback. The best I can offer in response is that I have seen them trigger a warning, usually caused by shoes or clothing which then need to be left behind. I am silently relieved that my shoes and trousers did not set off the machines after my momentary excursion into that grass verge.
\end{abstract}

The radioactive landscape of the Zone has offered a set of challenges, both to interpretive approaches and the wider trend towards practices and materialities. ${ }^{87}$ Where MerleauPonty's rejection of distance and dualism offered a useful starting point, it is clear that radiation's alien agencies and extra sensory forces challenges ontologies of co-incidence 
and any latent romanticism in any foundational intertwining between self and world. The model of exposure presented here draws from Irigaray's critiques to contribute to postphenomenological understandings of landscape salvaging the potential for more radically de-centering the perceiving, active subject .

Exposure is not just a model for tourism and radiation. Whether nuclear, chemical, microbial or otherwise, exposure to toxic and hazardous agents is a pervasive part of everyday life, albeit with greatly uneven geographies. ${ }^{88}$ Exposure is both an existential condition and a socially induced one,${ }^{89}$ something clearly apparent when comparing the tourists choice to visit the Zone and those who live with the ongoing effects of the disaster. But, despite this positional distance, exposure is a shared existential condition. Exposure, as a model for embodied subjectivity, requires a recognition of the foundational passivity and vulnerability which is the source of agency and embodied action, and takes seriously worldly forces, materialities and agencies ${ }^{90}$ by recognising them not as in withdrawal, or absent, but in excess of our bodily, perceptual and representational capacities; an inhabitation-by, exposure is a foundational relation-with worldly others not predicated upon exteriority. 
Firstly, exposure firstly posits a foundational passivity. My focus on tour-guiding and tourists, where the empirical materials here are bodies-in-action, has allowed me to show that this is not a passivity of inaction. For a politics of toxic geographies this avoids pathologising passivity and setting vulnerability in opposition to agency. Rather, exposure is a passivity (but not, necessarily, receptivity) in relation to affective materialities and worldly forces as the foundation of any and all action.

Secondly, exposure requires that we understand materialities and forces in excess and as excessive. They do not withdraw or exist as an 'absent presence' they exceed embodied, perceptual and representational worlds: Only partially, uncertainly knowable, and then only after we are already enmeshed within. As in the case of long-half lives for which contamination is counted in tens of thousands of years, this is an exposure to agencies, forces and materialities which are excessive in scale, both physical and temporal. This may be experienced as vulnerability, a certain kind of reflexive realisation, except that the self which this realisation returns to is not singular, unified. The response may, understandably, be to define and defend bodily boundaries. But this is after-the-fact, never fully making bodies and worlds knowable as distinct, bounded entities, such as the old body scanners, which, with their small lights and oddly not-quite-reassuring dull thunk identify bodies as exposed, irradiated, but defined as 'safe' or, rather, 'safe enough'. 
Finally, exposure names a relation to that which is not me, which is not masterable, proprietorial, and which is not exterior. Exposure is a foundational relation-with which precedes the subject as a coherent, bounded entity. I have shown how Irirgaray's mimetic critique offers the vital means to salvage the forgotten other Other in phenomenological thought. Through Irigaray, exposure understands the body-subject as that which is inhabited-by, prior to any intentional openness. The prior relation that is exposure is not one which would complete or unify the subject. Exposure is the condition of the embodied subject as, prior to all else, inhabited-by that which remains Other. Exposure is not subjectification as ceaseless becoming - not a co-production of selves and worlds exposure is the perpetual unravelling of the self.

\footnotetext{
1 J.Urry and J.Larsen, The Tourist Gaze 3.0 (London, Sage, 2011).

${ }^{2}$ See C.DeSilvey and T.Edensor, 'Reckoning with Ruins', Progress in Human Geography, 27 (2012); Paul Dobraszczyk, The Dead City: Urban Ruins and the Spectacle of Decay (London, I.B.Tauris, 2017).

${ }^{3}$ S. Kirsch, Proving Grounds: Project Plowshare and the Unrealized Dream of Nuclear Earthmoving (New Brunswick, Rutgers University Press, 2005).

${ }^{4}$ A.Petryna, Life Exposed: Biological Citizens after Chernobyl (Princeton, Princeton University Press, 2002); T.Davies and A.Polese, 'Informality and Survival in Ukraine's Nuclear Landscape: Living with the Risks of Chernobyl', Journal of Eurasian Studies 6 (2015).

${ }^{5}$ For an overview, see L.Pitkanen and M.Farish, 'Nuclear Landscapes', Progress in Human Geography 31 (2017).

${ }^{6}$ J.D.Dewsbury et al., 'Enacting Geographies', Geoforum 33 (2002), p.439.

${ }^{7}$ B.Alexis-Martin and T.Davies, 'Towards Nuclear Geography: Zones, Bodies, and Communities', Geography Compass 11 (2017).

8 Pitkanen and Farish, 'Nuclear Landscapes'

${ }^{9}$ G.Mitman, M.Murphy and C.Sellers, 'Introduction: A Cloud over History', Osiris 19 (2004)

10 J.Wylie, Landscape (Oxon, Routledge, 2007).

${ }^{11}$ D.Massey, 'Landscape as a Provocation: Reflections on Moving Mountains', Journal of Material Culture 11 (2006).

12 J.Wylie, 'Depths and Folds: On Landscape and the Gazing Subject', Environment and Planning D 24 (2006).
} 
${ }^{13}$ M.Rose and J.Wylie, 'Guest Editorial: Animating Landscape', Environment and Planning D 24 (2006).

14 J.Wylie, 'Landscape, Absence and the Geographies of Love', Transactions of the Institute of British Geographers 34 (2009).

${ }^{15}$ Wylie, 'Love'; P.Simpson, 'What Remains of the Intersubjective?: On the Presencing of Self and Other', Emotion, Space and Society 14 (2015); J.Ash and P.Simpson, 'Geography and Post-Phenomenology', Progress in Human Geography 40 (2016).

${ }^{16}$ M.Rose, 'Gathering "Dreams of Presence": A Project for the Cultural Landscape', Environment and Planning D 24 (2006); Wylie, 'Love'.

17 P.Harrison, 'Corporeal Remains: Vulnerability, Proximity, and Living on after the End of the World', Environment and Planning A 40 (2008).

18 P.Simpson, "'Failing on Deaf Ears": A Postphenomenology of Sonorous Presence', Environment and Planning A 41 (2009).

${ }^{19}$ see N.Rush-Cooper, 'Chernobyl and Stalker: "Splinters of the Soviet Empire"', Toxic News (2016). https://toxicnews.org/2016/05/03/chernobyl-and-stalker-splinters-of-the-soviet-empire/

20 Petryna, Life Exposed; S.D.Phillips, 'Chernobyl's Sixth Sense: The Symbolism of an Ever-Present Awareness', Anthropology and Humanism 29 (2004); T.Davies, 'A Visual Geography of Chernobyl: Double Exposure', International Labor and Working-Class History 84 (2013)

${ }^{21}$ E.Fraser, 'Urban Exploration as Adventure Tourism: Journeying Beyond the Everyday', in H.Andrews and L.Roberts eds. Liminal Landscapes: Travel, experience, and spaces in-between (Oxon, Routledge, 2016); Dobraszczyk, Dead City.

22 J.Goatcher and V.Brunsden, 'Chernobyl and the Sublime Tourist', Tourist Studies 11 (2011).

${ }^{23}$ S.Kirsch, 'Harold Knapp and the Geography of Normal Controversy: Radioiodine in the Historical Environment', Osiris 19 (2004)

${ }^{24}$ For a more in-depth discussion of my role as tour guide and the tourism context to the Zone, see N.Rush-Cooper, Exposures: Exploring Selves and Landscapes in the Chernobyl Exclusion Zone, PhD thesis (2013) http://etheses.dur.ac.uk/8490/

25 Health and Safety Executive, Occupational Exposure to lonising Radiation (2015). http://www.hse.gov.uk/statistics/ionising-radiation/cidi.pdf

${ }^{26}$ D.Cosgrove, Social Formation and Symbolic Landscape (Madison, University of Wisconsin Press, 1998).

27 D.Cosgrove, 'Prospect, perspective and the evolution of the landscape idea', Transactions of the Institute of British Geographers 10 (1985)

${ }^{28}$ Wylie, Landscape, p.86.

${ }^{29}$ M.Merleau-Ponty, Phenomenology of Perception, trans. D.A.Landes (London, Routledge, 2012).

30 Wylie, Landscape, p.86.

${ }^{31}$ H.Lorimer, 'Cultural geography: the busyness of being 'more-than-representational", Progress in

Human Geography 29 (2005)

32 Merleau-Ponty, Ph.P, p.70.

33 Op. cit., p.222.

${ }^{34}$ Merleau-Ponty, Ph.P, p. xxiv.

35 Grosz, Volatile Bodies.

${ }^{36}$ Wylie, 'Love', p.279.

37 Harrison, 'Corporeal Remains', p.429.

38 P. Harrison, 'In the Absence of Practice', Environment and Planning D 27 (2009). 
39 J.Butler, 'Rethinking Vulnerability and Resistance' in J.Butler, L.Sabsay and Z.Gambetti eds. Vulnerability in resistance (Durham, Duke University Press, 2016)

${ }^{40}$ Maurice Merleau-Ponty, The Visible and the Invisible, trans. Alphonso Lingis (Evanston, Northwestern University Press, 1968), p.200.

41 J.Wylie, 'An Essay on Ascending Glastobury Tor', Geoforum 33 (2002).

42 Merleau-Ponty, TV\&I, p.133.

43 Rose, 'Dreams', p.547.

${ }^{44}$ Grosz, Volatile Bodies, p.101.

45 P.Merriman et al., 'Landscape, Mobility, Practice', Social \& Cultural Geography 9 (2008), p.203.

${ }^{46}$ Wylie, 'Depths and Folds', p.531.

${ }^{47}$ Rose and Wylie, 'Animating Landscape'.

${ }^{48}$ L.Irigaray, The forgetting of air in Martin Heidegger (London, Athlone, 1999).

${ }^{49}$ Op cit., p.9.

50 L.Irigaray, 'To Paint the Invisible', Continental Philosophy Review 37 (2004), p.397.

51 Merleau-Ponty, TV\&I, p.265.

52 Op. cit., p.1005.

${ }^{53}$ Ash and Simpson, 'Post-Phenomenology', p.10.

${ }^{54}$ Wylie, 'Love', p.284.

55 P.Harrison, “"How Shall I Say It...?” Relating the Nonrelational', Environment and Planning A 39 (2007), p.601.

56 Simpson, 'What Remains', p.68.

57 Wylie, 'Love', p.279.

58 Op. cit., p.286.

59 Harrison, 'Nonrelational', p.602.

60 Op. cit., p.8 after Seigworth and Gregg, 2010

${ }^{61}$ S.Kirsch, 'Cultural Geography I: Materialist Turns', Progress in Human Geography 37 (2013), p.439.

62 Wylie, 'Love', p.286.

63 Harrison, 'Absence', p.999.

64 Simpson, "'Failing on Deaf Ears"'.

65 Merleau-Ponty, TV\&I, p.251.

66 Judith Butler, Senses of the Subject (New York, Fordham University Press, 2015), p,150.

${ }^{67}$ L.Irigaray An Ethics of Sexual Difference (London, Continuum, 2004).

68 L.Irigaray, Elemental Passions (London, Athlone Press, 1992).

${ }^{69}$ Op. cit., p.45.

70 Merleau-Ponty, Ph.P., p.222.

71 Irigaray, Ethics, p.144.

72 Irigaray, 'Paint', p.397.

73 Grosz, Volatile Bodies, p.107.

${ }^{74}$ V.Kirby, 'Culpability and the Double Cross: Irigaray with Merleau-Ponty', in Dorothea Olkowski and Gail Weiss eds. Feminist Interpretations of Maurice Merleau-Ponty (University Park, Pa, Pennsylvania State Univ. Press, 2006).

${ }^{75}$ R.Colls, 'Feminism, Bodily Difference and Non-Representational Geographies', Transactions of the Institute of British Geographers 37 (2012). 
${ }^{76}$ Irigaray, 'Paint', p.401.

77 Harrison, 'Corporeal Remains', p.430.

78 Op. cit., p.430.

${ }^{79}$ Simpson, 'What Remains', p.68.

${ }^{80}$ Irigaray, 'Paint', p.403.

81 Op. cit., p.394.

${ }^{82}$ Similar to Levinas in Harrison, 'The Space between Us'.

${ }^{83}$ Merleau-Ponty, TV\&I, p.263.

${ }^{84}$ T.Lorraine, Irigaray and Deleuze: Experiments in Visceral Philosophy (London, Cornell University Press, 1999), p.45.

${ }^{85}$ C.Vasseleu, Textures of Light Vision and Touch in Irigaray, Levinas, and Merleau-Ponty (London, Routledge, 2002), p.61.

${ }^{86}$ Rose, 'Dreams', p.547.

${ }^{87}$ Kirsch, 'Cultural Geography I'; D.Tolia-Kelly, 'The geographies of cultural geography III: Material geographies, vibrant matters and risking surface geographies', Progress in Human Geography 37 (2013) 88 T.Davies, 'Slow violence and toxic geographies: 'Out of sight' to whom?', Environment and Planning C: Politics and Space, OnlineFirst (2019)

${ }^{89}$ Butler, 'Rethinking Vulnerability and Resistance'

${ }^{90}$ Dewsbury, 'Enacting Geographies' 